\title{
ISOFLAVONES, PHENOLICS CONTENT AND ANTIOXIDANT ACTIVITY OF THREE EGYPTIAN SOYBEAN CULTIVARS
}

\section{BY}

\author{
Essam Abdel-Sattar ${ }^{1}$, Azza Ramy Abdel-Monem ${ }^{1}$, Mohamed Elamir F. Hegazy ${ }^{2}$, Ali M. El- \\ Halawany ${ }^{1}$, Sherif Mahmoud Afifi ${ }^{3 *}$ \\ FROM \\ ${ }^{1}$ Department of Pharmacognosy, College of Pharmacy, Cairo University, Cairo 11562, \\ Egypt. \\ ${ }^{2}$ Phytochemistry Department, National Research Centre, 12622, 33 El Bohouth St., Dokki, \\ Giza, Egypt. \\ ${ }^{3}$ Department of Pharmacognosy, Faculty of Pharmacy, University of Sadat City, Sadat City \\ 32897, Egypt.
}

\begin{abstract}
Soybean (Glycine max L.) is an important worldwide crop, mainly used as raw material for oil production, and the residue is mainly used as feedstuff. The medicinal functions of consuming soybean have been shown to be effective against number of chronic diseases such as cancer, heart disease, osteoporosis and menopausal symptoms. The objective of this work was to evaluate isoflavone and phenolic content and their antioxidant activity in three Egyptian soybean cultivars Giza 22, Giza 35 and Giza 111. Significant differences among the studied cultivars were found for genistein, daidzein, glycitein and total isoflavones due to genetic effects since all cultivars were collected at the same location. The total isoflavones ranged from $470.6 \mathrm{mg} / 100 \mathrm{~g}$ dry soybean (Giza 22) to 200.3 $\mathrm{mg} / 100 \mathrm{~g}$ (Giza 111). The rank of total phenolic content (TPC) was Giza $22>$ Giza $35>$ Giza 111. At a concentration of $10 \mathrm{mg} / \mathrm{mL}$, the free radical scavenging (antioxidant) capabilities were 79.34, 65.97 and $59.35 \%$ for the extracts of Giza 22, Giza 35 and Giza 111 , respectively. In conclusion, the present study or related studies are of great importance to identify the best soybean cultivar with the highest isoflavone content to be used as source for production of nutraceutical products rather than as a nutritional source of protein.
\end{abstract}

Keywords: HPLC, soybean cultivars, isoflavone, phenolic, antioxidant, Glycine max L.

\section{Introduction}

Soybean is recognized as an oil seed crop containing several useful nutrients including isoflavones, proteins, carbohydrates, vitamins and minerals. It can substitute for meat and to some extent for milk. It is a crop capable of reducing protein malnutrition as soybean protein provides all the eight essential amino acids in the daily amounts needed for human health. Past several years of scientific and clinical evidences had revealed the 
medicinal benefits of the soybean components against metabolic disorders (Hartman et al., 2011).

Consumption of soybean had been linked to promote many health conditions, especially in reducing the risk of various cancers (Messina, 1997; Johnson, 2011). It was confirmed that unique components of soybean, such as isoflavones and phenolic compounds play an important role in protecting against oxidative stress that causes the development of some chronic diseases (Pusparini et al., 2013). Soybean isoflavones have the potential to directly scavenge oxidants such as superoxide and nitric oxide or via indirect mechanisms, such as induction of antioxidant-scavenging enzymes (Yoon and Park, 2014).

Daidzein, glycitein and genistein are the three basic isoflavone aglycones, and daidzin, glycitin and genistin are the main corresponding isoflavone glycosides. The malonyl derivatives of these glucosides are also present in soybean (Kudou et al., 1991). Malonyl isoflavones are thermally unstable and can be easily decarboxylated to produce acetyl glycosides during sample preparation and analysis. In total, there are twelve isoflavones identified in soybean (Griffith and Collison, 2001).

Several studies indicate that genetic variability affects isoflavone content of soybean cultivars. Isoflavone content variations can also be attributed to annual changes in environmental conditions from different locations such as temperatures, humidity, light intensity and rainfall (Wang and Murphy, 1994a; Tsukamoto et al., 1995; Carrão-Panizzi et al., 1998). Therefore, the objective of this work was to evaluate isoflavone concentration in three Egyptian soybean cultivars Giza 22, Giza 35 and Giza 111 using HPLC equipped with a photodiode array detector, in addition to determination of phenolic content and antioxidant activity.

\section{Materials and methods}

Authenticated soybean seeds of Giza 22, Giza 35 and Giza 111 were obtained from Agricultural Research Center (ARC), Giza, Egypt. Ground seeds (100 g) were defatted overnight with $n$-hexane $(1: 10)$, then washed two times with $n$-hexane $(2 \mathrm{X} 300 \mathrm{~mL})$ and allowed to dry. The defatted samples were then extracted overnight with $80 \%$ methanol (2 $\mathrm{X} 500 \mathrm{~mL}$ ) followed by evaporation of the combined extracts under reduced pressure. Samples were prepared by dissolving $8 \mathrm{mg}$ extract in $3 \mathrm{~mL}$ methanol by sonication.

Genistein, daidzein and glycitein were purchased from Sigma-Aldrich (Steinheim, Germany), several concentrations $(0.2$ to $1 \mathrm{mg} / \mathrm{mL})$ of each isoflavone were prepared to construct the calibration curves. The test sample and external standard solutions were filtrated through $0.22 \mu \mathrm{m}$ syringe filter before injection into HPLC apparatus.

The isoflavone concentrations were determined according to Carrão-Panizzi et al. (2009) on HPLC Ultimate 3000 system equipped with a photodiode array detector (Bremen, Germany) running under Hystar software on a bounded silica C18 column (4.6 X $150 \mathrm{~mm}, 1.8 \mu \mathrm{m})$, column oven set at $30{ }^{\circ} \mathrm{C}$. The mobile phases are composed of $0.2 \%$ formic acid/water (A) and $0.2 \%$ formic acid/methanol (B). The column was equilibrated with $10 \% \mathrm{~B}$ in $\mathrm{A}$. The injection volume was $5 \mu \mathrm{L}$ at a flow rate of $0.5 \mathrm{~mL} / \mathrm{min}$. After 
injection, the column was run for $1 \mathrm{~min}$ at the initial conditions, then developed with a linear gradient from $10 \%$ to $100 \% \mathrm{~B} / \mathrm{A}$ in $35 \mathrm{~min}, 100 \% \mathrm{~B}$ for $4 \mathrm{~min}$ and from $100 \%$ to $10 \% \mathrm{~B}$ in $10 \mathrm{~min}$ (equilibration). The detecting wavelength was $285 \mathrm{~nm}$. Isoflavone peaks were identified by their spectra and retention time and confirmed by comparing with data obtained from previous analyses of soybean isoflavone mixtures. Concentrations of the isoflavones were calculated as their respective aglycones, expressed as means for three replications in $\mathrm{mg} / 100 \mathrm{~g}$ soybean powder.

The TPC was assessed in triplicate using gallic acid as the standard by FolinCiocalteu assay as described by Singleton et al. (1999). The absorbance was measured in triplicate at $765 \mathrm{~nm}$ against a reagent blank. The TPC was expressed as milligrams of gallic acid equivalents (mg of GAE/100 g soybean powder).

The in vitro free radical scavenging activity was determined using DPPH assay according to the method described by Burda and Oleszek (2001) with ascorbic acid as a standard.

\section{Results and discussion}

The twelve expected isoflavones are well resolved from one another and from background peaks (Figure 1). The total isoflavone content of Giza 22, Giza 35 and Giza 111 cultivars were 470.6, 377.9 and $200.3 \mathrm{mg} / 100 \mathrm{~g}$ soybean powder, respectively. For daidzein, the highest average value was found in Giza $22(201.3 \mathrm{mg} / 100 \mathrm{~g})$, while, Giza 35 cultivar had the highest value of glycitein $(172.8 \mathrm{mg} / 100 \mathrm{~g})$. For genistein, the highest average value was observed in Giza $22(159.9 \mathrm{mg} / 100 \mathrm{~g})$. In addition, Giza 111 cultivar showed the lowest content of daidzein and glycitein (Table 1).

Mujić et al. (2011) reported that total isoflavone content in different Croatian soybean cultivars was in the range from 80.7 to $213.6 \mathrm{mg} / 100 \mathrm{~g}$. Several authors considered the isoflavones as the major phenolic compounds and their concentration in different soybean varieties varied from 126.1 to $409.2 \mathrm{mg} / 100 \mathrm{~g}$ of soybean (Wang and Murphy, 1994b; Carrão-Panizzi and Kitamura, 1995). The total isoflavone content in five Japanese and Chinese soybean varieties were reported by Yamabe et al. (2007) in the range from 221 to $444 \mathrm{mg} / 100 \mathrm{~g}$. Soybean isoflavones have a positive impact on human health including prevention of chronic diseases such as cancer, heart disease, osteoporosis and menopausal symptoms (Zaheer and Humayoun, 2017). 


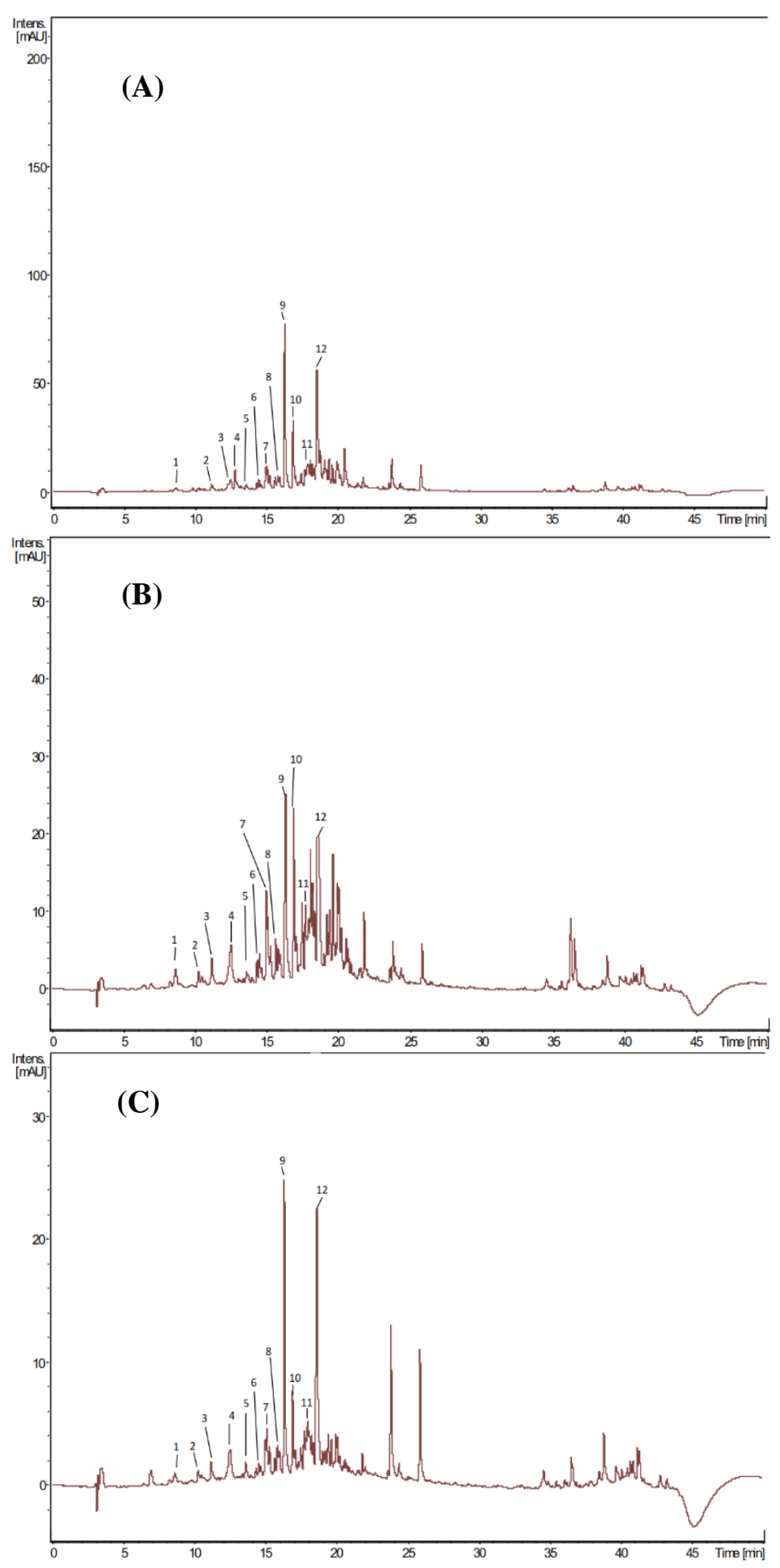

Figure 1. HPLC analysis of isoflavones in (A) Giza 22, (B) Giza 35 and (C) Giza 111 
1: daidzin; 2: glycitin; 3: genistin; 4: malonyl daidzin; 5: malonyl glycitin; 6: acetyl daidzin; 7: acetyl glycitin; 8: malonyl genistin; 9: daidzein; 10: glycitein; 11: acetyl genistin; 12: genistein

Table 1. Mean contents of daidzein, glycitein, genistein and total isoflavones of the three studied cultivars

\begin{tabular}{|c|c|c|c|c|}
\hline \multirow{2}{*}{ Cultivars } & \multicolumn{4}{|c|}{ Content of isoflavone (mg/100 g of soybean) } \\
\cline { 2 - 5 } & Daidzein & Glycitein & Genistein & Total \\
\hline Giza 22 & 201.3 & 109.4 & 159.9 & $\mathbf{4 7 0 . 6}$ \\
\hline Giza 35 & 143.7 & 172.8 & 61.4 & $\mathbf{3 7 7 . 9}$ \\
\hline Giza 111 & 88.5 & 33.4 & 78.4 & $\mathbf{2 0 0 . 3}$ \\
\hline
\end{tabular}

The TPC of the three investigated cultivars Giza 22, Giza 35 and Giza 111 was 695, 580 and $525 \mathrm{mg} \mathrm{GAE} / 100 \mathrm{~g}$ soybean, respectively. Chung et al. (2011) estimated the TPC in Korean soybean and it reached $366 \mathrm{mg} / 100 \mathrm{~g}$ soybean. Moreover, Malenčić et al. (2007) published results of TPC of different soybean genotypes from Serbia where total phenolic content ranged from 270 to $488 \mathrm{mg} / 100 \mathrm{~g}$. Guzmán-Ortiz et al. (2017) reported similar TPC values for soybean collected from Mexico at concentration of $548 \mathrm{mg} / 100 \mathrm{~g}$.

Giza 22, Giza 35 and Giza 111 cultivars showed scavenging capabilities of 79.34, 65.97 and $59.35 \%$, respectively, while ascorbic acid $(1 \mathrm{mg} / \mathrm{mL})$ showed inhibition activity of $91.74 \%$. The DPPH free radical scavenging test has been widely used for evaluating antioxidant activity of grain and cereal extracts (Yu et al., 2002; Masisi et al., 2016). In this study, the order of the DPPH radical quenching capabilities also was in agreement with their concentration of phenolic content. Similar results were published by Mujić et al. (2011) where antioxidant activity of soybeans also correlated well with TPC. The uses of natural antioxidants from plant extracts have experience growing interest due to some human health professionals and consumer's concern about the safety of synthetic antioxidants in foods (Santos-Sanchez et al., 2017).

\section{Conclusion}

The rank of antioxidant activity was Giza $22>$ Giza $35>$ Giza 111. A greater quantity of isoflavone content, phenolic compounds and antioxidant capacity could be provided by Giza 22 cultivar as compared with Giza 35 and Giza 111 soybeans. 


\section{REFERENCES}

Burda, S. and Oleszek, W. (2001). Antioxidant and antiradical activities of flavonoids. Journal of Agricultural and Food Chemistry; 49(6), 2774-2779.

Carrão-Panizzi, M. C., Berhow, M., Mandarino, J. M. G. and Oliveira, M. C. N. d. (2009). Environmental and genetic variation of isoflavone content of soybean seeds grown in Brazil. Pesquisa Agropecuária Brasileira; 44(11), 1444-1451.

Carrão-Panizzi, M. C. and Kitamura, K. (1995). Isoflavone Content in Brazilian Soybean Cultivars. Breeding Science; 45(3), 295-300.

Carrão-Panizzi, M. C., Kitamura, K., Belera, A. and Oliveira, M. C. N. (1998). Influence of Growth Locations on Isoflavone Contents in Brazilian Soybean Cultivars. Japanese Journal of Breeding; 48(4), 409-413.

Chung, I. M., Seo, S. H., Ahn, J. K. and Kim, S. H. (2011). Effect of processing, fermentation, and aging treatment to content and profile of phenolic compounds in soybean seed, soy curd and soy paste. Food Chemistry; 127(3), 960-967.

Griffith, A. P. and Collison, M. W. (2001). Improved methods for the extraction and analysis of isoflavones from soy-containing foods and nutritional supplements by reversed-phase high-performance liquid chromatography and liquid chromatography-mass spectrometry. J Chromatogr A; 913(1-2), 397-413.

Guzmán-Ortiz, F. A., San Martín-Martínez, E., Valverde, M. E., Rodríguez-Aza, Y., Berríos, J. D. J. and Mora-Escobedo, R. (2017). Profile analysis and correlation across phenolic compounds, isoflavones and antioxidant capacity during germination of soybeans (Glycine max L.). CyTA - Journal of Food; 15(4), 516-524.

Hartman, G. L., West, E. D. and Herman, T. K. (2011). Crops that feed the World 2. Soybean-worldwide production, use, and constraints caused by pathogens and pests. Food Security; 3(1), 5-17.

Johnson, I. T. (2011). Anti-tumour properties of functional foods. In M. Saarela (Ed.) Functional Foods. (pp. 202-233) Cambridge, England: Woodhead Publishing, 2nd ed.

Kudou, S., Fleury, Y., Welti, D., Magnolato, D., Uchida, T., Kitamura, K., et al. (1991). Malonyl Isoflavone Glycosides in Soybean Seeds (Glycine max Merrill). Agricultural and Biological Chemistry; 55(9), 2227-2233.

Malenčić, D., Popović, M. and Miladinović, J. (2007). Phenolic content and antioxidant properties of soybean (Glycine max (L.) Merr.) seeds. Molecules; 12(3), 576-581.

Masisi, K., Beta, T. and Moghadasian, M. H. (2016). Antioxidant properties of diverse cereal grains: A review on in vitro and in vivo studies. Food Chemistry; 196, 90-97.

Messina, M. J. (1997). Soyfoods: Their Role in Disease Prevention and Treatment. In K. Liu (Ed.) Soybeans: Chemistry, Technology, and Utilization. (pp. 442-447) New York, USA: Chapman and Hall.

Mujić, I., Šertović, E., Jokić, S., Sarić, Z., Alibabić, V., Vidović, S., et al. (2011). Isoflavone content and antioxidant properties of soybean seeds. Croatian Journal of Food Science and Technology; 3(1), 16-20.

Pusparini, Dharma, R., Suyatna, F. D., Mansyur, M. and Hidajat, A. (2013). Effect of soy isoflavone supplementation on vascular endothelial function and oxidative 
stress in postmenopausal women: a community randomized controlled trial. Asia Pac J Clin Nutr; 22(3), 357-364.

Santos-Sanchez, N. F., Salas-Coronado, R., Valadez-Blanco, R., Hernandez-Carlos, B. and Guadarrama-Mendoza, P. C. (2017). Natural antioxidant extracts as food preservatives. Acta Scientiarum Polonorum Technologia Alimentaria; 16(4), 361370.

Singleton, V. L., Orthofer, R. and Lamuela-Raventós, R. M. (1999). Analysis of total phenols and other oxidation substrates and antioxidants by means of folin-ciocalteu reagent. Methods in enzymology; 299(1), 152-178.

Tsukamoto, C., Shimada, S., Igita, K., Kudou, S., Kokubun, M., Okubo, K., et al. (1995). Factors Affecting Isoflavone Content in Soybean Seeds: Changes in Isoflavones, Saponins, and Composition of Fatty Acids at Different Temperatures during Seed Development. Journal of Agricultural and Food Chemistry; 43(5), 1184-1192.

Wang, H. and Murphy, P. A. (1994a). Isoflavone Composition of American and Japanese Soybeans in Iowa: Effects of Variety, Crop Year, and Location. Journal of Agricultural and Food Chemistry; 42(8), 1674-1677.

Wang, H. and Murphy, P. A. (1994b). Isoflavone Content in Commercial Soybean Foods. Journal of Agricultural and Food Chemistry; 42(8), 1666-1673.

Yamabe, S., Kobayashi-Hattori, K., Kaneko, K., Endo, H. and Takita, T. (2007). Effect of soybean varieties on the content and composition of isoflavone in rice-koji miso. Food Chemistry; 100(1), 369-374.

Yoon, G. A. and Park, S. (2014). Antioxidant action of soy isoflavones on oxidative stress and antioxidant enzyme activities in exercised rats. Nutr Res Pract; 8(6), 618-624.

Yu, L., Perret, J., Davy, B., Wilson, J. and Melby, C. L. (2002). Antioxidant Properties of Cereal Products. Journal of Food Science; 67(7), 2600-2603.

Zaheer, K. and Humayoun, A. M. (2017). An updated review of dietary isoflavones: Nutrition, processing, bioavailability and impacts on human health. Critical Reviews in Food Science and Nutrition; 57(6), 1280-1293. 
محتوى الايزوفلافونات والفينولات والفعالية المضادة للأكسدة لثثلاث انواع زراعية مصرية لفول الصويا للسادة الاكاترة

عصام عبد الستار '، عزة رامي عبد المنعم '، محمد الأمير حجازي '، علي الحلواني '، شريف محمود عفيفي ب* مسـن

$$
\text { ' قسم العقاقير - كلية الصيدلة - جامعة القاهرة - r r } 11 \text { القاهرة - مصر }
$$

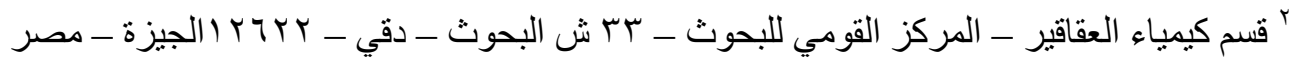

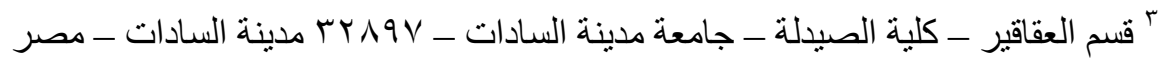

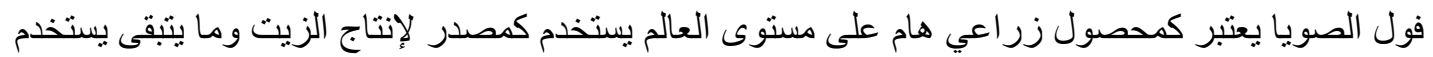

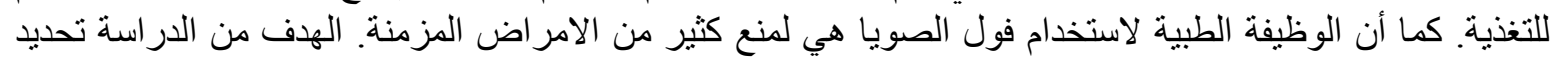

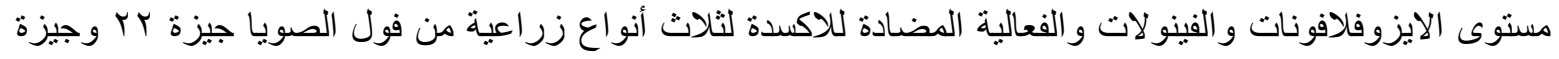

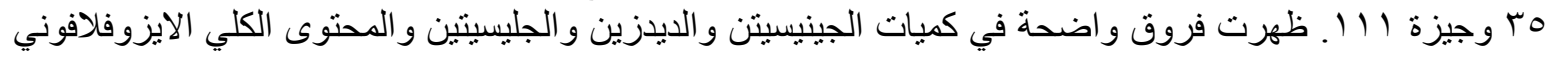

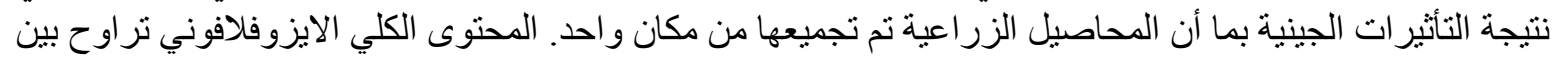

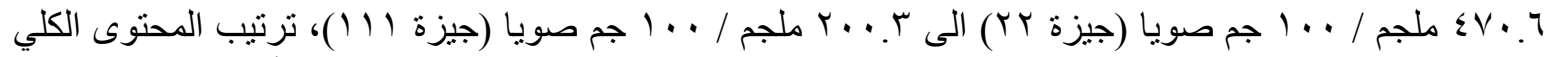

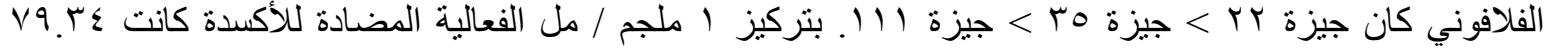

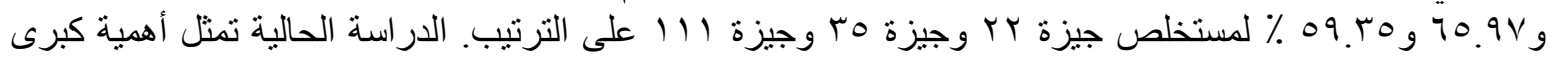
لمعرفة أي الانواع الزراعية أفضل بأُعلى محتوى ايزوفلافوني من اجل الجل الاستخدام كمستحضر دوائي غذائي بخلاف كونه مصدر للبروتين الغذائي. 